\title{
EFFECT OF MOISTURE CONTENT OF GREEN SAND ON THE CASTING DEFECTS
}

\author{
Nanang Qosim ${ }^{1 *}$, AM Mufarrih ${ }^{2}$, Ali Sai'in ${ }^{3}$, A. Hanif Firdaus ${ }^{4}$, Fina Andika F. A. ${ }^{5}$, Ratna \\ Monasari $^{6}$ \& Zakki F. Emzain ${ }^{7}$ \\ Department of Mechanical Engineering, Politeknik Negeri Malang ${ }^{1,2,4,5,6,7}$ \\ Department of Mechanical Engineering, Politeknik Negeri Semarang ${ }^{3}$ \\ nanangqsm@polinema.ac.id ${ }^{1}$
}

Received : 18 May 2020, Revised: 5 August 2020, Accepted : 6 August 2020

\begin{abstract}
In this study, three percentages of moisture content on the green sand were benchmarked to be observed their effects on the casting defects. The metal used is scrap Al-Si with wt\% of Al 59.7. The metal was melted in a furnace at $550{ }^{\circ} \mathrm{C}$ then poured into sand molds and cooled for 24 hours before it can be removed, cleaned, and finished. There were prepared three specimens for each benchmark. Qualitative observation of defects was done by physical observations on the surface of the specimens. The observations show that on the moisture content of $2.5 \%$, there is a defect in the form of porosity. Defects in the form of drops, misruns, blowholes, and shrinkage cavity are found on the benchmark 3.5\%. The most severe defects are found on the benchmark $4.5 \%$ in the form of buckles and severe shrinkage cavities that are found in almost all specimens.
\end{abstract}

Keywords : Sand Casting, Green Sand, Moisture Content, Al-Si, Casting Defects.

\section{Introduction}

The needs of metal turned out to be not only limited to objects with a flat surface. The need for metals is also growing rapidly along with the technology that supports it. Now, we can produce metal products in any form without having to go through the forging process. Metal casting is a production process using metal or non-metal that has been melted and casted to produce products with shapes that are close to the final geometrical shape of the product. Metal or non-metal that has been melted in the smelting furnace at a certain temperature will be poured or pressed into a mold that has a cavity in accordance with the desired shape. The mold is removed from the metal or nonmetal casting after the melting metal or nonmetal fills the cavity and returns to solid form (Chastain, 2004; Sama \& Manogharan, 2017; Surdia \& Chijiwa, 2006).

The metal used in this study is scrap aluminum. Based on data from Pemkot Malang (city local government), waste production for all types in Malang is around 664 tons per day in early 2020 . The amount of $90 \%$ has been handled well with the principle of reducing, reusing, and recycling, and will continue to be optimized. This study intends to support this optimization by utilizing the scrap aluminum as raw material for metal casting products.

\section{Literature Review}

Several studies have examined the parameters of the sand casting. Research by Astika et al. showed that the addition of bentonite as binding agents affected the permeability and compressive strength of sand molds, whereas the type of sand did not have a significant effect (Astika, Negara, \& Susantika, 2010). With the same method, Siagian et al. experimented by adding Si element, where the porosity of the casting product increased with the increasing percentage of Si (Siagian, Gede, Istri, \& Dan Kusuma, 2017). Desiana, et. al. in their study claimed that the higher the addition of water glass to the green sand the more water content increased (Desiana, 2012). In the other study, Taryaman varied the percentage of moisture content and bentonite in the green sand, which obtained the best quality result at a moisture content of $4 \%$ with bentonite of $8.14 \%$ (Taryaman, Roslina, \& Abdullah, 2018).

In this study, the moisture content will be varied into 3 benchmarks to be observed their effects on the casting defects formed. The casting defects as shown on Fig. 1. may be attributed to the following reasons: (a) defects due to faulty mold: these include blow holes, scab, buckle, 
fusion, crusher, swells, shifts, shrinkage, hot tears, hard spot, etc. (b) defects due to improper metal and mode of pouring: these include misruns, cold shut, shot metal, gas porosity, inclusion, etc. (c) defects due to faulty design of pattern: these include warping, shrinkage, cracks, porosity, hot spots, hot tear, etc. (Kaushish, 2010).

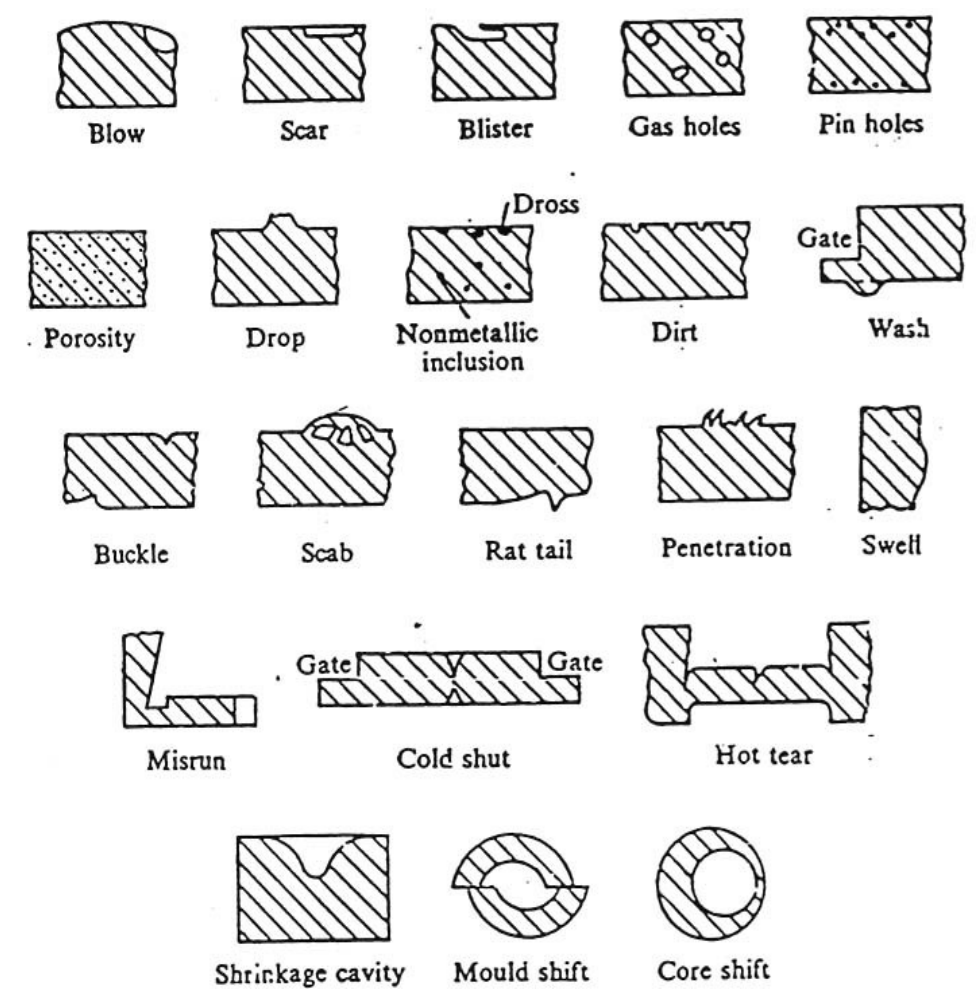

Fig. 1. Types of casting defects (Surdia \& Chijiwa, 2006)

The International Committee of Foundry Technical Association has developed a standard nomenclature of the following seven basic categories of casting defects. (a) metallic projections such as fins, flash, and mismatch. (b) cavities including internal and exposed cavities, blowholes, pinholes, etc. (c) discontinuities such s cracks and hot tears. (d) defective surface such as fusion and penetration crushes, scabs, hard spots, surface folds, laps, scars, blister, etc. (e) incomplete casting comprising misruns, cold shut and pour short. (f) incorrect dimensions and shape such as warping and shrinkage. (g) inclusion such as non-metallic particles and oxides in the metal matrix (Kaushish, 2010; Surdia \& Chijiwa, 2006).

\section{Research Methods}

This study begins with the preparation of green sand based on $\mathrm{SiO}_{2}$. The sand is cleaned of impurities and sieved with a mesh sieve 10 to separate the sand from the rocks. Then $10 \%$ of bentonite and the moisture content varied by $2.5 \%, 3.5 \%$, and $4.5 \%$ are added. Determination of the moisture content is done by taking 20 grams of sand samples that have been prepared and then dried in an oven chamber at the temperature of 105 to $110^{\circ} \mathrm{C}$. Drying is carried out until a constant weight is achieved. The calculation of the moisture content in green sand is determined by equation 1 . below (Hendronursito \& Prayanda, 2016):

$\%$ moisture content $=\frac{\text { Weight of aggregate (gr) }- \text { Dry weight of aggregate (gr) }}{\text { Dry weight of aggregate (gr) }} \times 100$

Before the casting process is carried out, the scrap aluminum to be casted has been scanned using the XRF test to determine the elements contained in that metal, where the results are shown in Table 1. below. 
Table 1 - The composition of elements

\begin{tabular}{ccc}
\hline No. & Element & Concentration Unit (\%) \\
\hline 1 & $\mathrm{Al}$ & 59.7 \\
2 & $\mathrm{Si}$ & 15.0 \\
3 & $\mathrm{P}$ & 1.5 \\
4 & $\mathrm{Ca}$ & 2.47 \\
5 & $\mathrm{Ti}$ & 0,26 \\
6 & $\mathrm{~V}$ & 0.072 \\
7 & $\mathrm{Cr}$ & 0.21 \\
8 & $\mathrm{Mn}$ & 0.26 \\
9 & $\mathrm{Fe}$ & 3.41 \\
10 & $\mathrm{Ni}$ & 8.36 \\
11 & $\mathrm{Cu}$ & 8.69 \\
\hline
\end{tabular}

Aluminum smelting is carried out in a melting furnace using a crucible (a vessel that holds the molten metal). Aluminum is melted at the melting temperature ranges from 500-550 ${ }^{\circ} \mathrm{C}$. After the aluminum is poured into the mold as shown in Fig. 2., then the casting is cooled for about 24 hours. Afterward, the mold is disassembled to remove the specimen. Qualitative observation of defects is carried out by making physical observations on the surface of the castings.

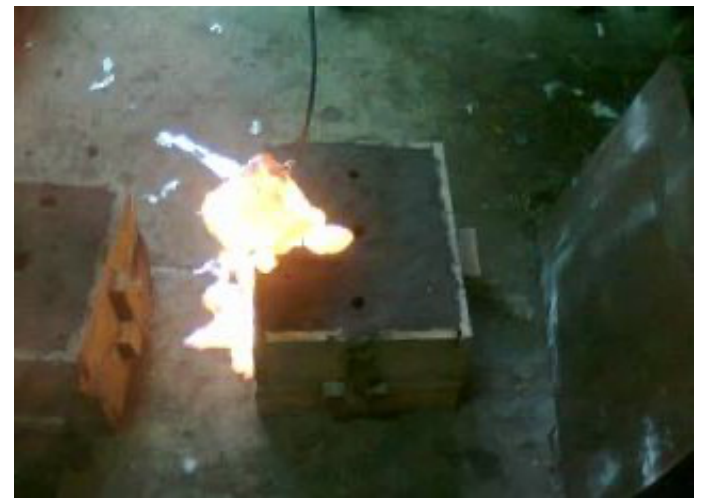

Fig. 2. Pouring the melting aluminum into the sand mold

\section{Results and Discussions}

\subsection{Moisture Content of 2,5\%}

The specimens with the moisture content of $2.5 \%$ are shown in Fig. 3a. Fig. 3b. shows porosity defect in form pinholes. Pinholes are very tiny holes found in the cope outer part of the mold, in a poorly vented pocket. These casting defects are sometimes referred to as porosities. This occurs because most liquid materials can hold a large amount of dissolved gas, but the solid form of the same material cannot, so the gas forms bubbles within the material as it cools. Nitrogen, oxygen, and hydrogen are the most encountered gases in cases of porosity. In aluminum castings, hydrogen is the only gas that dissolves in significant quantity, which can result in hydrogen gas porosity. For casting that are a few kilograms in weight, the pores are usually 0.01 to $0.5 \mathrm{~mm}$ (0.00039 to 0.01969 in) in size (De Garmo, Black, \& Kohser, 2003; Vaishnav \& Patel, 2016). 

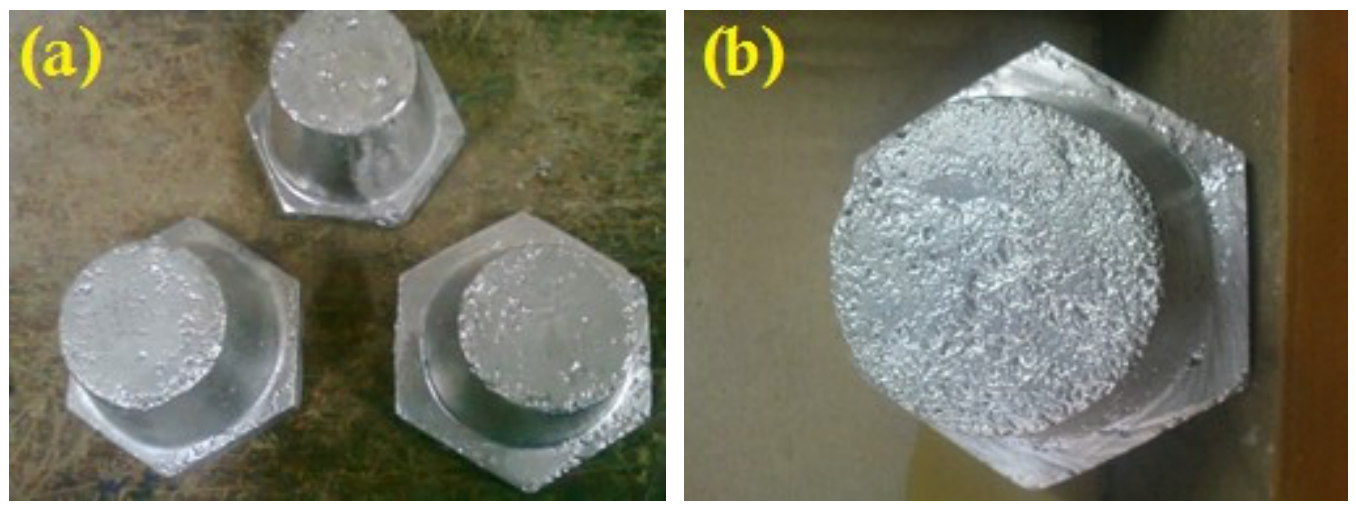

Fig. 3. (a) The specimens with the moisture content of 2.5\%; (b) Th porosity defect on the surface of the specimen

To prevent the defect, the material may be melted in a vacuum, in an environment of low-solubility gases, such as argon or carbon dioxide, or under a flux that prevents contact with the air. To minimize gas solubility the superheat temperatures can be kept low. Turbulence from pouring the liquid metal into the mold can introduce gases, so the molds are often streamlined to minimize such turbulence. Other methods include vacuum degassing, gas flushing, or precipitation. Precipitation involves reacting the gas with another element to form a compound that will form dross that floats to the top (De Garmo et al., 2003; Jatimurti, Alexander, \& Toto Wibisono, 2019).

\subsection{Moisture Content of 3,5\%}

There are found some types of casting defects on the specimens with the moisture content of 3.5\% as shown in Fig. 4. Fig. 4.a shows the defect in the form of drops (see the red circles). Drops show up as irregular bumps on the tops of castings. They're caused when the mold is weak and sand falls into the liquid metal. Drops also make the metal surface dirty. Two main factors can cause drops. First, low refractoriness of clay or sand. Refractoriness is the ability of the molding material to resist the temperature of the liquid so it does not fuse with the metal. Silica sand has the highest refractoriness. The other factor is too high pouring temperature of molten metal. Hence, improving the refractoriness of the molding material and reducing the pouring temperature of the molten metal will help prevent casting defects in the form of drops.

The casting defect in the form of misrun is found on one of three specimens in this benchmark. The misrun occurs when the liquid metal does not completely fill the mold cavity, leaving an unfilled portion, as shown in Fig. 4.b. This defect is caused by either a lack of fluidity in the molten Aluminum or cross-sections that are too narrow. The fluidity can be increased by changing the chemical composition of the metal or by increasing the pouring temperature. Another possible cause is back pressure from improperly vented mold cavities.
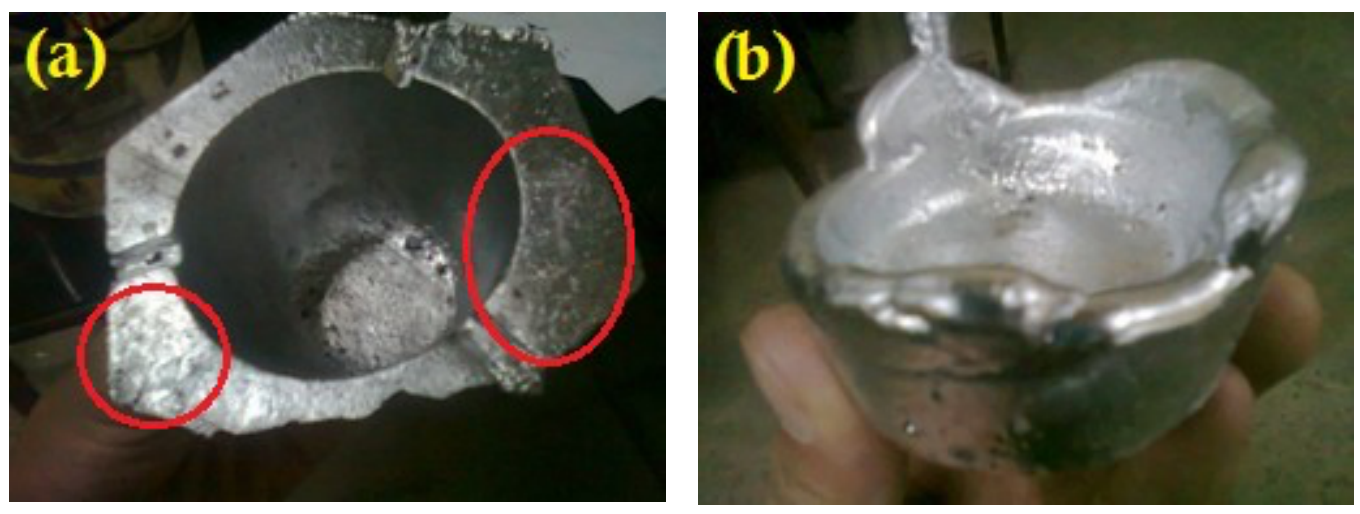

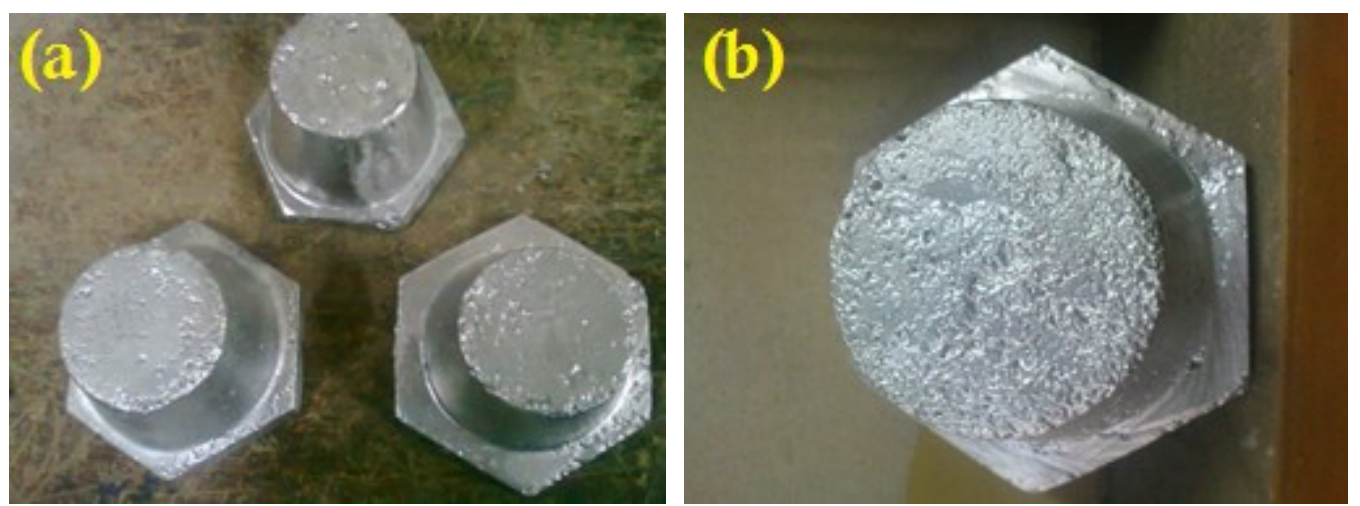

Fig. 4. The casting defect of benchmark 3,5\% (see red circles): (a) drops; (b) misruns; (c) blowholes or blister; (d) shrinkage cavity

Fig. 4.c. shows the blowholes or blisters occur on the surface of the specimen (see red circles). Blowholes are larger holes in the upper part of the casting. The cause and prevention of this defect are similar to pinholes or porosities. The larger in the shape of casting defects that occur on this benchmark is the shrinkage cavity (see red circle on Fig. 4.d). The shrinkage cavity is a depression or an internal void in casting that results from the volume contraction that occurs during solidification (Sharma, 2007). Shrinkage defects show up when the liquid metal in the mold is not all the same temperature. There are two possible causes for this. Either the metal being poured into the mold is too hot or the metal is solidifying unevenly. The shrinkage casting defects can be prevented by improving the overall casting structure which includes, designing a running (gate) system with risers to enables a continuous flow of molten metal, reduce casting temperature to reduce the total volume deficit and by increasing local heat dissipation by inserting cooling ribs or coils, and internal chills.

\subsection{Moisture Content of $4,5 \%$}

The last is the result of Al-Si casting with a variation of moisture content of $4.5 \%$. As shown in Fig. 5., physically, the results of casting with this benchmark have some very severe defects in all specimens. Fig. 5.a shows a severe defect in the form of buckles. The buckle is a type of mold material defect that more severe form of rat tails. Rat tails and buckles occur when excessive heat of the metal causes the sand to expand. This may be caused by poor expansion properties of the sand, a hot pouring temperature, Poor mold design. Hence, the preventions of this defect can be done by adding combustible additives to sand, reducing the pouring temperature of the metal, and redesigning the mold (large and flat sections are more prone to rat tails. The mold also should not be too hard, as it must allow for proper expansion). Afterward, Fig. 5.b and 5.c show the casting defect in the form of severe shrinkage cavities. The cause and the prevention of this defect have been discussed before in section 3.2.
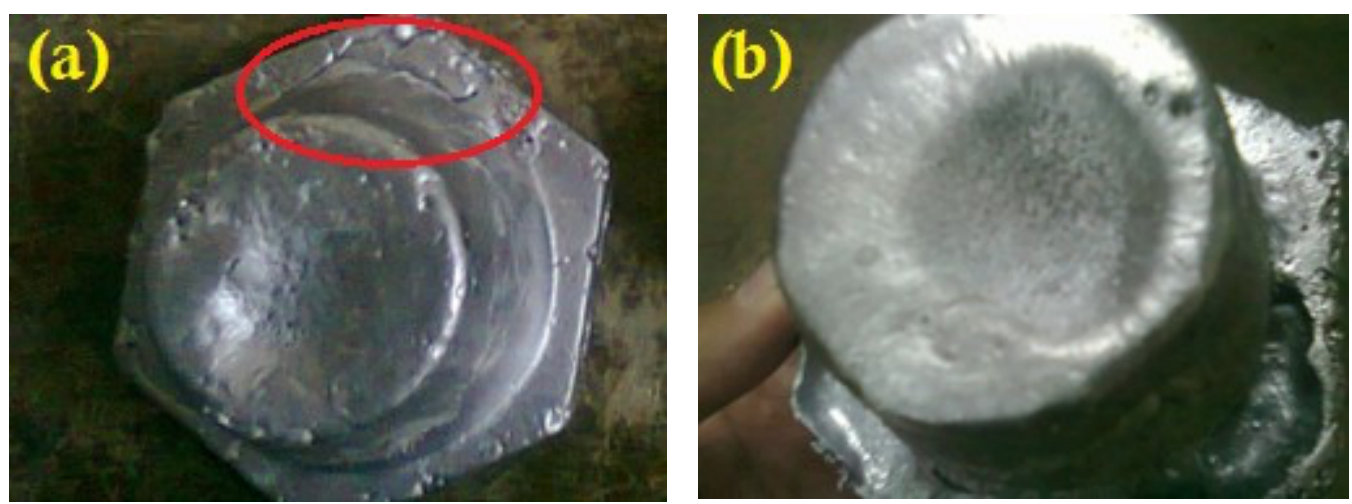


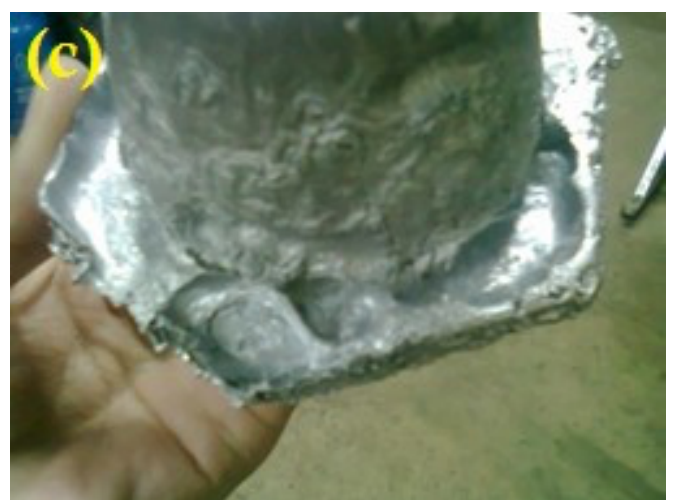

Fig. 5. The casting defect of benchmark 4,5\%: (a) buckle (see red circle); (b) \& (c) severe shrinkage cavities

\section{Conclusion}

From this study of various variations of the moisture content on the green sand, it can be seen that the most appropriate moisture content to produce a better product in the sand casting process is $2.5 \%$, although some porosity defects are still found. Porosity defects are common defects and are difficult to avoid in the process of metal casting metal, but we can minimize the cause with the methods that have been discussed.

\section{References}

Astika, I. M., Negara, D. P., \& Susantika, M. A. (2010). Pengaruh Jenis Pasir Cetak dengan Zat Pengikat Bentonit terhadap Sifat Permeabilitas dan kekuatan Tekan Basah Cetakan Pasir (Sand Casting). Jurnal Energi Dan Manufaktur.

Chastain, S. (2004). Metal Casting: A Sand Casting Manual for the Small Foundry.

De Garmo, E. P., Black, J., \& Kohser, R. (2003). Materials and processes in manufacturing, Hoboken. In: NJ: Wiley.

Desiana, S. (2012). Pengaruh Variasi Waterglass Terhadap Kadar Air Dan Kadar Lempung Pada Pasir Cetak.

Hendronursito, Y., \& Prayanda, Y. (2016). Potensi Pasir Lokal Tanjung Bintang Pada Aluminium Sand Casting Terhadap Porositas Produk Hasil Cor Aluminium. Jurnal Kajian Teknik Mesin, 1(2), 60-68.

Jatimurti, W., Alexander, B., \& Toto Wibisono, A. (2019). Effect of Degassing Time and Cooling Rate on Microstructure and Porosity of Aluminum 6061 Alloy Using Sand Casting Method. Paper presented at the Materials Science Forum.

Kaushish, J. P. (2010). Manufacturing Processes.: PHI Learning.

Sama, S. R., \& Manogharan, G. (2017). Sand casting design rules: Pennsylvania State Univesrity.

Sharma, P. C. (2007). Production Technology (Manufacturing Processes): Manufacturing Processes: S. Chand.

Siagian, S. J., Gede, I., Istri, C., \& Dan Kusuma, P. J. J. I. T. D. M. (2017). Pengaruh Permeabilitas Cetakan Pasir Dan Penambahan Silikon (Si) Pada Proses Pengecoran Terhadap Kekerasan, Porositas Dan Struktur Mikro Alumunium Silikon (Al-Si). 6(4), 305-310.

Surdia, T., \& Chijiwa, K. (2006). Teknologi Pengecoran Logam Cetakan ke sembilan. Jakarta: Pradnya Paramita.

Taryaman, T., Roslina, R., \& Abdullah, H. (2018). Analisis Cacat Cor pada Produk Fly Wheel Hasil Proses Pengecoran Menggunakan Cetakan Pasir. Metal Indonesia, 27(1), 44-55.

Vaishnav, A., \& Patel, V. (2016). Reduce Shrinkage-Porosity Defects in Sand Casting Using FEM. 